\title{
The Effects of Two Quaternary Ammonium Compounds on Gitric Acid and Sterol Synthesis in Aspergillus niger
}

\author{
By T. S. RAMAN ANd E. R. B. SHANMUGASUNDARAM \\ University Biochemical Laboratory, Madras-25, India
}

(Received 13 July 1962)

\begin{abstract}
SUMMARY
A mono-quaternary amine, cetyltrimethylammonium bromide (Cetrimide), and a bisquaternary diamine, triclobisonium chloride (Triburon), were examined for their action on Aspergillus niger. Cetrimide, at $30 \mu \mathrm{g} . /$ ml. inhibited growth, but the organism was not inhibited by as much as $1.28 \mathrm{mg}$. Triburon $/ \mathrm{ml}$. Cetrimide at $20 \mu \mathrm{g} . / \mathrm{ml}$. inhibited citric acid accumulation. Triburon, at concentrations up to $160 \mu \mathrm{g} . / \mathrm{ml}$., increased the citric acid concentration, the maximum yield being at $40 \mu \mathrm{g}$. Triburon/ml.; at higher concentrations of Triburon there was an inhibition of citric acid production. The effect of Triburon was still perceptible in the presence of ferric ions. Cetrimide and Triburon brought about an initial increase in sterol concentration, followed by a decrease at higher concentrations of these compounds. The effects of these compounds on citric acid production by preformed mycelia were similar to the effect on cultures growing from spores.
\end{abstract}

\section{INTRODUCTION}

The use of quaternary ammonium compounds as topical antibacterial substances has become increasingly popular in recent times. A new class of these compounds, belonging to the bisquaternary group, has shown promise as systemic therapeutic agents as well (Schnitzer, Grunberg \& DeLorenzo, 1960). Quaternary ammonium compounds are known to be comparatively innocuous to spore-forming organisms. A preliminary study in our laboratory showed a monoquaternary ammonium compound (cetyltrimethylammonium bromide, Cetrimide) to be highly inhibitory to the growth of Aspergillus niger, whereas a bisquaternary diamine (triclobisonium chloride, Triburon) was completely ineffective. The present paper deals with the effects of the two compounds on the growth and some aspects of the metabolism of $A$. niger.

\section{METHODS}

Triclobisonium chloride, $N, N^{\prime}$-bis[1-methyl-3-(2,2,6,-trimethylcyclohexyl)propyl]$N, N^{\prime}$-dimethyl-1,6-hexanediamine bis(methochloride), (Triburon), was a gift from Hoffmann-La Roche, Inc., Basle (see Schnitzer, Grunberg, DeLorenzo \& Bagdon, 1959). Cetrimide (cetyltrimethylammonium bromide) was the gift of Imperial Chemical Industries, Ltd.

Organism. The citric acid-accumulating strain of Aspergillus niger (Wisc. 72-4) was used, and was maintained by monthly subculture on potato glucose agar slopes.

Growth experiments. The organism was grown in $100 \mathrm{ml}$. conical flasks containing $10 \mathrm{ml}$. of the basal medium, which contained (g./l.); glucose, 150; $\mathrm{NH}_{4} \mathrm{NO}_{3}, \mathbf{2 . 5}$; 
$\mathrm{KH}_{2} \mathrm{PO}_{4}, 2 \cdot 5 ; \mathrm{MgSO}_{4} .7 \mathrm{H}_{2} \mathrm{O}, 0 \cdot 25 ; \mathrm{MnSO}_{4} .4 \mathrm{H}_{2} \mathrm{O}, 0 \cdot 1$; and $\mathrm{ZnSO}_{4} .7 \mathrm{H}_{2} \mathrm{O}, 1 \cdot 25 \mathrm{mg}$./.; dissolved in triple glass-distilled water, and adjusted to $\mathrm{pH} 2.5$ with $\mathrm{HCl}$. The flasks were plugged with cottonwool and sterilized by autoclaving at $115^{\circ}$ for $15 \mathrm{~min}$, After cooling they were inoculated with a spore suspension from a 7-day slope culture. The flasks were incubated at $30^{\circ}$ without shaking for the specified periods. After killing the organism by autoclaving, the mycelial mats were taken out, washed under the tap to remove spores, squeezed between filter-paper sheets and dried at $100^{\circ}$. The dry weight of the mycelium was used as a measure of growth.

Addition of the inhibitors. Cetrimide and Triburon were used as aqueous solutions and were either autoclaved in the basal medium, or sterilized separately by Seitz filtration and then added aseptically to previously autoclaved basal medium. Both methods gave identical results.

Experiments with resting mycelia of Aspergillus niger. The replacement technique used by Chughtai \& Walker (1954) was adopted with minor modifications. The organism was initially grown for 4 days in $10 \mathrm{ml}$. lots of basal medium in $100 \mathrm{ml}$. conical flasks. On the 4th day, the culture medium was withdrawn and replaced aseptically with an equal volume of sterile basal medium without glucose. The flasks were then incubated overnight to make the mycelia use up any adsorbed glucose. The liquid in the flasks was again withdrawn and replaced with $10 \mathrm{ml}$. of $5 \%$ glucose solution, with or without the addition of the inhibitors as desired, and the flasks incubated at $30^{\circ}$ for $24 \mathrm{hr}$.

Estimation of total acid and citric acid. Total acid was determined by titration of the culture medium against $0 \cdot 1 \mathrm{~N}-\mathrm{NaOH}$ to $\mathrm{pH} 8 \cdot 0$. Citric acid was estimated by the colorimetric method of Saffran \& Denstedt (1948).

Estimation of sterol. The dry mycelium was repeatedly extracted by grinding with acetone + ethanol $(1+1$ by vol. $)$ mixture. Sterols were estimated in the extracts by the method of Vahouny, Mayer, Roe \& Treadwell (1960). Pure ergosterol, freshly recrystallized from ethyl acetate and dried in vacuo was used as a standard.

Estimation of glucose. Glucose consumption was measured by estimating the glucose remaining in the medium by the colour reaction with anthrone (Seifter, Dayton, Novic \& Muntwyler, 1950).

Oxygen consumption of Aspergillus niger mycelium in presence of Cetrimide or Triburon. The organism was grown on the usual basal medium for 4 days, by which time uniformly thick mycelia formed. The mats were taken out, washed with distilled water, and pieces of equal weight $(250 \mathrm{mg}$. fresh weight) cut out and placed in Warburg flasks of $16 \mathrm{ml}$. capacity, containing $3.0 \mathrm{ml}$. fresh basal medium, and different concentrations of the inhibitors. The gas phase was air, and oxygen consumption was measured by conventional methods (Umbreit, Burris \& Stauffer, 1951) during $6 \mathrm{hr}$. at $30^{\circ}$. Oxygen consumption of mycelia grown in presence of the inhibitors was similarly measured.

\section{RESULTS}

The effect of Cetrimide and Triburon on growth, citric acid production and sterol concentration in Aspergillus niger

The ineubation periods were 5 and 8 days. Under the conditions used, maximum acid production and growth was obtained at the end of 5 days; and when the 
incubation was continued longer, the yield of citric acid and the mycelial weight both decreased. The results in Table 1 show that Cetrimide was inhibitory to the organism. Triburon, on the other hand, seemed to increase the mycelial weight. Sub-inhibitory concentrations of Cetrimide increased the sterol content two- to threefold, but had practically no effect on the formation of citric acid. Triburon produced similar, but less pronounced increases in sterol concentration. Intermediate concentrations of Triburon more than double citric acid formation. At higher concentrations, Triburon inhibited citric acid formation.

Table 1. The effect of Cetrimide and Triburon on growth, total acid, citric acid and sterol of Aspergillus niger

The average of ten separate experiments, each in triplicate, is presented below.

\begin{tabular}{|c|c|c|c|c|c|c|c|c|}
\hline \multirow{2}{*}{$\begin{array}{l}\text { Additions } \\
\text { to medium } \\
(\mu \mathrm{g} . / \mathrm{ml} .)\end{array}$} & \multicolumn{2}{|c|}{$\begin{array}{l}\text { Dry weight } \\
\text { mycelium } \\
\text { (mg.) }\end{array}$} & \multicolumn{2}{|c|}{$\begin{array}{c}\text { Total acid } \\
(\mathrm{ml} .0 \cdot 1 \mathrm{~N}-\mathrm{NaOH})\end{array}$} & \multicolumn{2}{|c|}{$\begin{array}{r}\text { Citric acid } \\
\text { (mg./flask) }\end{array}$} & \multicolumn{2}{|c|}{$\begin{array}{l}\text { Sterol content } \\
\text { of mycelium } \\
(\mu \mathrm{g} . / 100 \mathrm{mg} . \\
\text { dry mycelium) }\end{array}$} \\
\hline & 5 days & 8 days & 5 days & 8 days & 5 days & 8 days & 5 days & 8 days \\
\hline None & 222 & 169 & $39 \cdot 6$ & $33 \cdot 5$ & 282 & 239 & 292 & 325 \\
\hline \multicolumn{9}{|l|}{ Cetrimide } \\
\hline 0.8 & 223 & 172 & $38 \cdot 9$ & $32 \cdot 8$ & 282 & 244 & 342 & 406 \\
\hline $1 \cdot 6$ & 220 & 172 & $37 \cdot 8$ & $34 \cdot 0$ & 276 & 236 & 618 & 687 \\
\hline $3 \cdot 2$ & 215 & 175 & $38 \cdot 8$ & $\mathbf{3 3} \cdot \mathbf{3}$ & 280 & 239 & 698 & 776 \\
\hline $6 \cdot 4$ & 226 & 169 & $38 \cdot 7$ & $32 \cdot 8$ & 285 & 242 & 788 & 877 \\
\hline $10 \cdot 0$ & 209 & 170 & $35 \cdot 6$ & $30 \cdot 1$ & 269 & 249 & 705 & 784 \\
\hline $12 \cdot 8$ & 198 & 168 & $34 \cdot 0$ & $29 \cdot 8$ & 260 & 235 & 458 & 510 \\
\hline $20 \cdot 0$ & 179 & 174 & $2 \cdot 8$ & $23 \cdot 3$ & 20 & 165 & 179 & 198 \\
\hline $30 \cdot 0$ & \multicolumn{2}{|c|}{ No growth } & - & - & - & - & 一 & - \\
\hline \multicolumn{9}{|l|}{ Triburon } \\
\hline 0.8 & 223 & 174 & $53 \cdot 0$ & $44 \cdot 8$ & 377 & 320 & 343 & 382 \\
\hline $1 \cdot 6$ & 225 & 169 & $57 \cdot 9$ & $48 \cdot 9$ & 410 & 349 & 389 & 435 \\
\hline $\mathbf{3 \cdot 2}$ & 223 & 172 & $75 \cdot 1$ & $64 \cdot 9$ & 544 & 465 & 551 & 606 \\
\hline $6 \cdot 4$ & 223 & 175 & $90 \cdot 5$ & $76 \cdot 6$ & 646 & 550 & 455 & 507 \\
\hline $12 \cdot 8$ & 225 & 170 & $106 \cdot 8$ & $88 \cdot 7$ & 758 & 634 & 316 & 352 \\
\hline $20 \cdot 0$ & 229 & 171 & $110 \cdot 4$ & $90 \cdot 6$ & 789 & 646 & 297 & 324 \\
\hline $40 \cdot 0$ & 233 & 176 & $120 \cdot 0$ & $95 \cdot 9$ & 855 & 682 & 292 & 325 \\
\hline $80 \cdot 0$ & 259 & 198 & $102 \cdot 1$ & $86 \cdot 1$ & 726 & 613 & 279 & 311 \\
\hline $160 \cdot 0$ & 282 & 222 & $89 \cdot 6$ & $82 \cdot 4$ & 631 & 586 & 265 & 307 \\
\hline $320 \cdot 0$ & 288 & 254 & $39 \cdot 2$ & $31 \cdot 2$ & 275 & 216 & 247 & 309 \\
\hline $640 \cdot 0$ & 285 & 280 & $31 \cdot 6$ & $31 \cdot 5$ & 225 & 225 & 241 & 303 \\
\hline $1280 \cdot 0$ & 283 & 282 & $3 \cdot 7$ & $31 \cdot 4$ & 26 & 220 & 219 & 309 \\
\hline
\end{tabular}

Glucose consumption was also studied in the same flasks by estimating the residual glucose; these results are presented in Table 2, including the yields of citric acid on the basis of glucose consumed. No significant effect of either substance on glucose consumption was observed, except for the inhibition produced by the highest concentrations of Cetrimide; in this case only the fermentation period of 5 days was studied.

Effect of Triburon on citric acid production in the presence of ferric ion

Since the effect of Triburon on citric acid production (Table 1) somewhat resembles the effect of ferric ion (see Perlman, Dorrell \& Johnson, 1946; Shu \& Johnson, 
Table 2. The effect of Cetrimide and Triburon on glucose consumption and yield of citric acid by Aspergillus niger, growing from a spore inoculum

The results presented are the average of ten separate experiments. The fermentation period was 5 days.

\begin{tabular}{|c|c|c|}
\hline $\begin{array}{l}\text { Additions to } \\
\text { basal medium } \\
\text { ( } \mu \mathrm{g} . / \mathrm{ml} .) \\
\text { None }\end{array}$ & $\begin{array}{c}\text { Glucose } \\
\text { consumed } \\
(\%) \\
\mathbf{9 7 \cdot 1}\end{array}$ & $\begin{array}{c}\text { Yield of } \\
\text { citric acid } \\
\text { (g./100 g. } \\
\text { glucose } \\
\text { consumed) } \\
19 \cdot 4\end{array}$ \\
\hline \multicolumn{3}{|l|}{ Cetrimide } \\
\hline $\begin{array}{r}0 \cdot 8 \\
1 \cdot 6 \\
3 \cdot 2 \\
6 \cdot 4 \\
10 \cdot 0 \\
12 \cdot 8 \\
20 \cdot 0\end{array}$ & $\begin{array}{l}96 \cdot 8 \\
97 \cdot 2 \\
98 \cdot 4 \\
97 \cdot 9 \\
97 \cdot 5 \\
88 \cdot 3 \\
60 \cdot 1\end{array}$ & $\begin{array}{l}19.5 \\
18.9 \\
19 \cdot 0 \\
19 \cdot 4 \\
18 \cdot 4 \\
19 \cdot 6 \\
22 \cdot 2\end{array}$ \\
\hline \multicolumn{3}{|l|}{ Triburon } \\
\hline 0.8 & $98 \cdot 2$ & $25 \cdot 6$ \\
\hline $1 \cdot 6$ & $98 \cdot 0$ & $27 \cdot 9$ \\
\hline $3 \cdot 2$ & $97 \cdot 4$ & $37 \cdot 2$ \\
\hline $6 \cdot 4$ & $97 \cdot 8$ & $44 \cdot 0$ \\
\hline $12 \cdot 8$ & $98 \cdot 4$ & $51 \cdot 4$ \\
\hline $20 \cdot 0$ & $97 \cdot 9$ & 53.7 \\
\hline 40.0 & $98 \cdot 2$ & $58 \cdot 1$ \\
\hline $80 \cdot 0$ & $98 \cdot 3$ & $49 \cdot 2$ \\
\hline $160 \cdot 0$ & $97 \cdot 9$ & $43 \cdot 0$ \\
\hline $320 \cdot 0$ & $98 \cdot 4$ & $18 \cdot 6$ \\
\hline $640 \cdot 0$ & $98 \cdot 1$ & $15 \cdot 3$ \\
\hline $1280 \cdot 0$ & $98 \cdot 1$ & $1 \cdot 8$ \\
\hline
\end{tabular}

Table 3. The effect of Triburon on citric acid production by Aspergillus niger, in the presence of ferric ion

The results presented are the average of eight separate experiments. The fermentation period was 5 days.

\begin{tabular}{|c|c|c|c|c|c|c|}
\hline \multirow{2}{*}{$\begin{array}{l}\text { Triburon } \\
\text { added to } \\
\text { medium } \\
(\mu \mathrm{g} . / \mathrm{ml} .)\end{array}$} & \multicolumn{2}{|c|}{$\begin{array}{l}\text { Dry weight of } \\
\text { mycelium } \\
\text { (mg.) }\end{array}$} & \multicolumn{2}{|c|}{$\begin{array}{l}\text { Citric acid } \\
\text { produced } \\
\text { (mg./flask) }\end{array}$} & \multicolumn{2}{|c|}{$\begin{array}{c}\text { Sterol content } \\
\text { of mycelium } \\
(\mu \mathrm{g} . / 100 \mathrm{mg} . \text { dry weight }\end{array}$} \\
\hline & $\begin{array}{c}\mathrm{Fe}^{3+} \\
1 \mathrm{mg} / \mathrm{l} .\end{array}$ & $\begin{array}{c}\mathrm{Fe}^{3+} \\
15 \mathrm{mg} \cdot / 1 .\end{array}$ & $\begin{array}{c}\mathrm{Fe}^{\mathrm{s}+} \\
1 \mathrm{mg} \cdot / \mathrm{l} .\end{array}$ & $\begin{array}{c}\mathrm{Fe}^{\mathrm{s}+} \\
15 \mathrm{mg} \cdot / 1 .\end{array}$ & $\begin{array}{c}\mathrm{Fe}^{3+} \\
1 \mathrm{mg} \cdot / \mathrm{l} .\end{array}$ & $\begin{array}{c}\mathrm{Fe}^{\mathrm{s}+} \\
15 \mathrm{mg} \cdot / \mathrm{l} .\end{array}$ \\
\hline 0.0 & 225 & 223 & 542 & 72 & 305 & 294 \\
\hline 0.8 & 223 & 223 & 694 & 92 & $\mathbf{3 4 7}$ & 339 \\
\hline $1 \cdot 6$ & 226 & 226 & 760 & 100 & 407 & 401 \\
\hline 3.2 & 222 & 224 & 822 & 109 & 575 & 553 \\
\hline 6.4 & 219 & 225 & 859 & 114 & 462 & 450 \\
\hline 12.8 & 224 & 220 & 889 & 118 & 316 & 322 \\
\hline 20.0 & 230 & 225 & 952 & 127 & 290 & 296 \\
\hline 40.0 & 234 & 237 & 1066 & 144 & 289 & 286 \\
\hline 80.0 & 260 & 255 & 862 & 117 & 270 & 272 \\
\hline $160 \cdot 0$ & 279 & 283 & 848 & 109 & 268 & 259 \\
\hline $320 \cdot 0$ & 284 & 282 & 528 & 69 & 255 & 247 \\
\hline 640.0 & 284 & 289 & 506 & 65 & 248 & 247 \\
\hline 1280.0 & 289 & 280 & 34 & 5 & 224 & 210 \\
\hline
\end{tabular}


1948) in so far as the yield of citric acid increased at first with increasing concentrations of Triburon, and then sharply decreased almost to zero, we examined whether this effect would persist in the presence of ferric ion. Two concentrations of iron were used, one being optimum for citric acid accumulation, and the other causing about $75 \%$ inhibition of citric acid accumulation. These concentrations were determined in a separate experiment, and agreed with those reported by Shu \& Johnson (1948). It was found that the effects of Triburon did persist in the two concentrations of iron, as shown in Table 3. The consumption of glucose was the same in the presence of iron as in its absence, and hence the highest amount of citric acid produced under the combined action of Triburon and iron represents a yield of about $\mathbf{7 2} \%$ on the basis of glucose consumed.

Table 4. The effect of Cetrimide and Triburon on glucose consumption and citric acid synthesis by preformed mycelia of Aspergillus niger

The mycelia were incubated at $30^{\circ}$ for $24 \mathrm{hr}$. in $5 \%$ glucose solution. The results presented are the average of ten separate experiments.

$\begin{array}{ccc}\begin{array}{c}\text { Additions to } \\ \text { medium } \\ (\mu \mathrm{g} \cdot / \mathrm{ml} .)\end{array} & \begin{array}{c}\text { Glucose } \\ \text { consumed } \\ \text { (\% initial } \\ \text { concentration) }\end{array} & \begin{array}{c}\text { Citric acid } \\ \text { produced } \\ \text { (mg./flask) }\end{array} \\ \text { None } & \mathbf{5 3} & 45 \\ \text { Cetrimide } & & \\ 4 \cdot 0 & 54 & 47 \\ 8 \cdot 0 & 52 & 45 \\ 12 \cdot 0 & 55 & 44 \\ 16 \cdot 0 & 50 & 46 \\ 20 \cdot 0 & 27 & 22 \\ 40 \cdot 0 & 1 & 0 \\ \text { Triburon } & & \\ 4 \cdot 0 & 54 & 45 \\ 8 \cdot 0 & 53 & 57 \\ 12 \cdot 0 & 54 & 74 \\ 16 \cdot 0 & 50 & 102 \\ 20 \cdot 0 & 51 & 154 \\ 40 \cdot 0 & 54 & 98 \\ 80 \cdot 0 & 52 & 46 \\ 160 \cdot 0 & 50 & 28 \\ 320 \cdot 0 & 52 & 7 \\ 640 \cdot 0 & 14 & 0 \\ & & 54\end{array}$

Effect of Cetrimide and Triburon on citric acid synthesis and glucose utilization by preformed mycelium of Aspergillus niger

Mycelia were incubated at $30^{\circ}$ for $24 \mathrm{hr}$. after the addition of the replacement medium and different concentrations of the inhibitors. No measurable growth took place during this period. Citric acid and glucose were estimated in the culture fluid; the results are shown in Table 4. Intermediate concentrations of Triburon were found to stimulate citric acid production, whereas Cetrimide had no such effect. 


\section{Oxygen consumption of Aspergillus niger mycelium under the influence of Cetrimide and Triburon}

The inhibitors, at the concentrations used $(0.4 \mathrm{mg}$. Cetrimide $/ \mathrm{ml}$.; $2.0 \mathrm{mg}$. Triburon/ml.), did not significantly affect oxygen consumption of Aspergillus niger mycelium. Oxygen consumption of mycelia grown in the presence of the two substances also did not differ significantly from that of normal mycelium.

\section{DISCUSSION}

The wide difference in the potencies of the two quaternary amines as inhibitors of Aspergillus niger is surprising. We have found (unpublished) that Cetrimide and Triburon are almost equally efficient (on a weight basis) in inhibiting the growth of such diverse organisms as Saccharomyces cerevisiae, Torula utilis, several lactic acid bacteria, Escherichia coli, Staphylococcus aureus and Streptomyces griseus. Further, no alteration in the sterol concentration was caused by the two inhibitors in such of the above organisms as contain sterol. The toxicity of both the quaternary amines for micro-organisms, including $A$. niger, increases with increasing $\mathrm{pH}$ value of the medium (unpublished work), whereas their detergent properties would decrease. Besides, the minimum concentration of Cetrimide required for micelleformation, which is considered to be essential for detergent action, appears to be several times higher than the concentration at which inhibitory action becomes manifest. Hence, it seems reasonable to assume that the differences in the properties of the two quaternary amines cannot be attributed to the lack of detergent properties of the diamine Triburon.

Yields of citric acid corresponding to $70 \%$ of glucose consumed have been reported in submerged as well as surface fermentation (Shu \& Johnson, 1948; Perlman, Dorrell \& Johnson, 1946). However, we did not obtain such high yields in our usual basal medium. The high yields obtained in the presence of suitable concentrations of Triburon, taken in conjunction with the lack of effect of the compound on glucose consumption, makes it look as though Triburon specifically alters glucose metabolism in favour of citric acid accumulation. Triburon causes alterations in the amounts of citric acid and of sterol, the effects being qualitatively similar. This would suggest that Triburon affects the synthesis or utilization of a common precursor, such as acetate, if it be assumed that most of the citric acid in Aspergillus niger is formed via the tricarboxylic acid cycle (see Ramakrishnan, Steel \& Lentz, 1955; Bomstein \& Johnson, 1952). However, it may be noted that Cetrimide, while greatly increasing the concentration of sterol, had no significant effect on citric acid synthesis. The data on oxygen consumption and glucose utilization suggest that effects of the inhibitors on these functions would not account for the observed effects on citric acid accumulation. The persistence of the influence of Triburon on citric acid production in the presence of ferric ion shows that the effects of this bisquaternary diamine and of the metal are independent of each other.

The help of Mrs Yeshodha G. Duraiswami in confirming some of the results is acknowledged with pleasure. One of the authors (T.S.R.) is the holder of a research fellowship of the Council of Scientific \& Industrial Research, India. 


\section{REFERENCES}

Bomstein, R. A. \& Johnson, M. J. (1952). The mechanism of formation of citrate and oxalate by Aspergillus niger. J. biol. Chem. 198, 143.

ChughtaI, I. D. \& Waxker, T. K. (1954). The mechanism of formation of organic acids by mould fungi. 6. The influence of cyanide on Aspergillus niger. Biochem. J. 56, 484.

Perlman, D., Dorrell, W. W. \& Johnson, M. J. (1946). The effect of metallic ions on the production of citric acid by Aspergillus niger. Arch. Biochem. 11, 131.

Ramakrishnan, C. V., Steel, R. \& Lentz, C. P. (1955). The mechanism of citric acid formation and accumulation in Aspergillus niger. Arch. Biochem. Biophys. 55, 270.

Saffran, M. \& Denstedt, O. (1948). A rapid method for the determination of citric acid. J. biol. chem. 175, 849.

Schnitzer, R. J., Grunberg, E. \& DeLorenzo, W. F. (1960). In vivo antistaphylococcal activity of bisquaternary diamines. Antibiotics Annual, 1959-60, p. 785.

Schnitzer, R. J., Grunberg, E., DeLorenzo, W. F. \& Bagdon, R. E. (1959). Triclobisonium chloride (Triburon), an antimicrobial with local activity in living host tissue. Antib. \& Chemo. 9, 267.

Seifter, S., Dayton, S., Novic, B. \& Muntwyler, E. (1950). The estimation of glycogen with the anthrone reagent. Arch. Biochem. 25, 191.

Shu, P. \& Johnson, M. J. (1948). Citric acid production by submerged fermentation with Aspergillus niger. Industr. Engng Chem. 40, 1202.

Umbreit, W. W., Burris, R. H. \& Stauffer, J. F. (1951). Manometric Methods and Tissue Metabolism. Minneapolis: Burgess Publishing Co.

Vahouny, G. V., Mayer, R. M., Roe, J. H. \& Treadwell, C. R. (1960). Determination of 3- $\beta$-hydroxy sterols with anthrone reagent. Arch. Biochem. Biophys. 86, 210. 